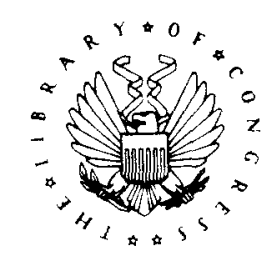

Washington. D.C. 20540

\section{Congressional Research Service The Library of Congress}

INDIVIDUAL RETIREMENT ACCOUNTS (IRAS)

IP0177I

Recent changes in the Nation's tax laws have made Individual Retirement Accounts available to many people previously excluded. Enclosed is general information on IRAs including material explaining these recent changes and their consequences.

Additional information on this subject, primarily in periodicals and newspapers, may be found in a local library through the use of indexes such as the Readers' Guide to Periodical Literature, Public Affairs Information Service Bulletin (PAIS), and the New York Times Index.

We hope this information will be helpful.

\title{
COMPLIMENTS OF Gene Snyder
}





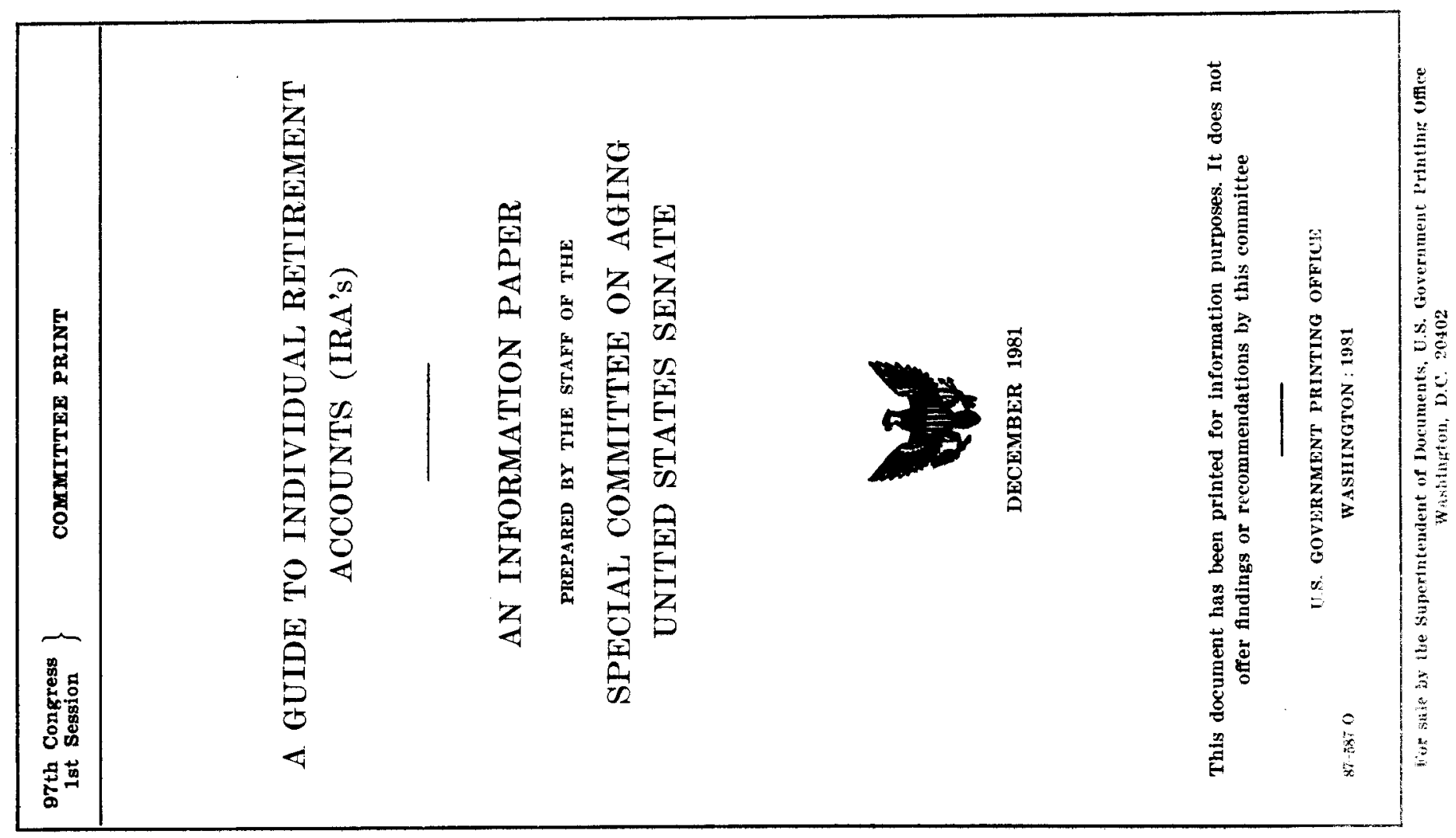






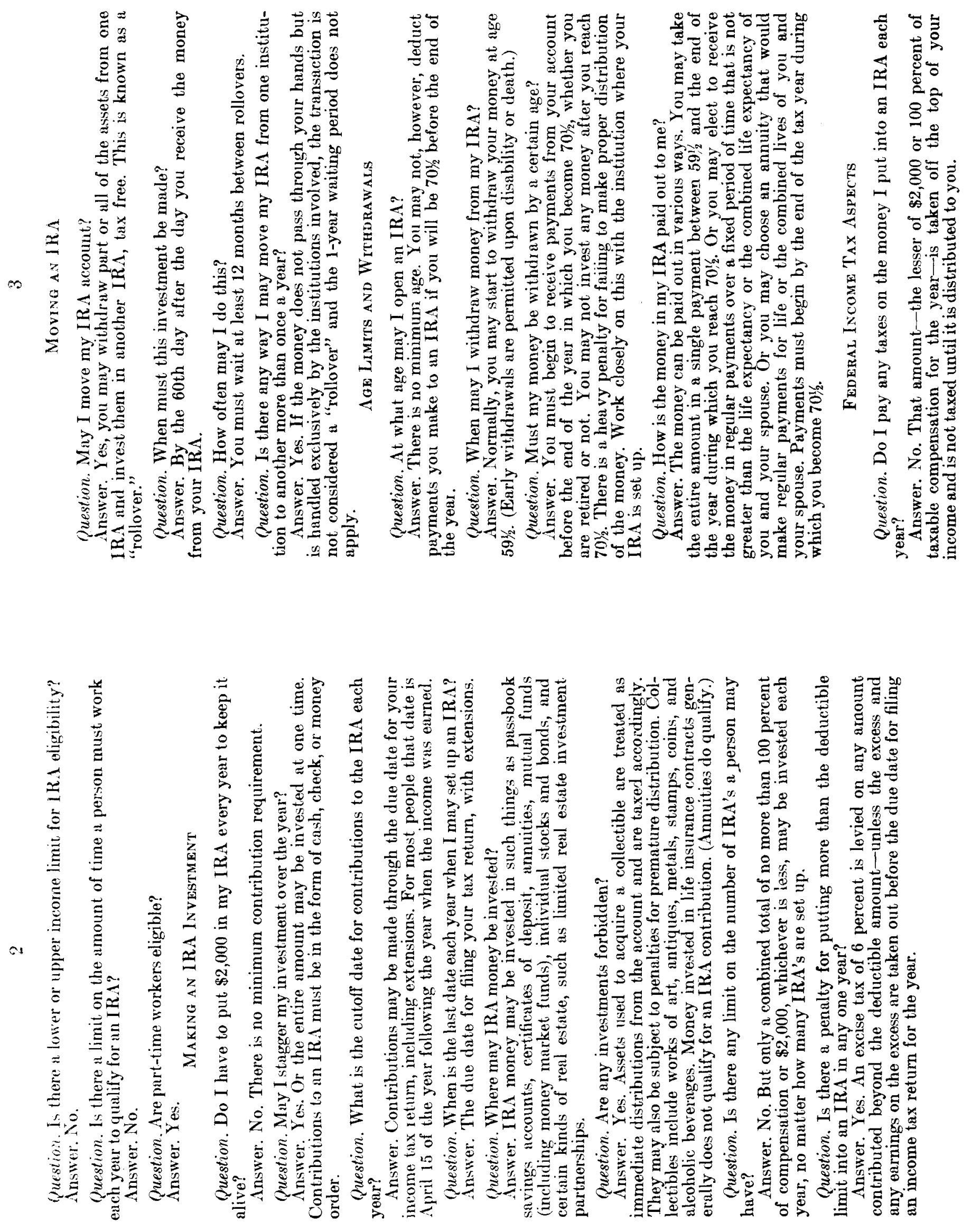


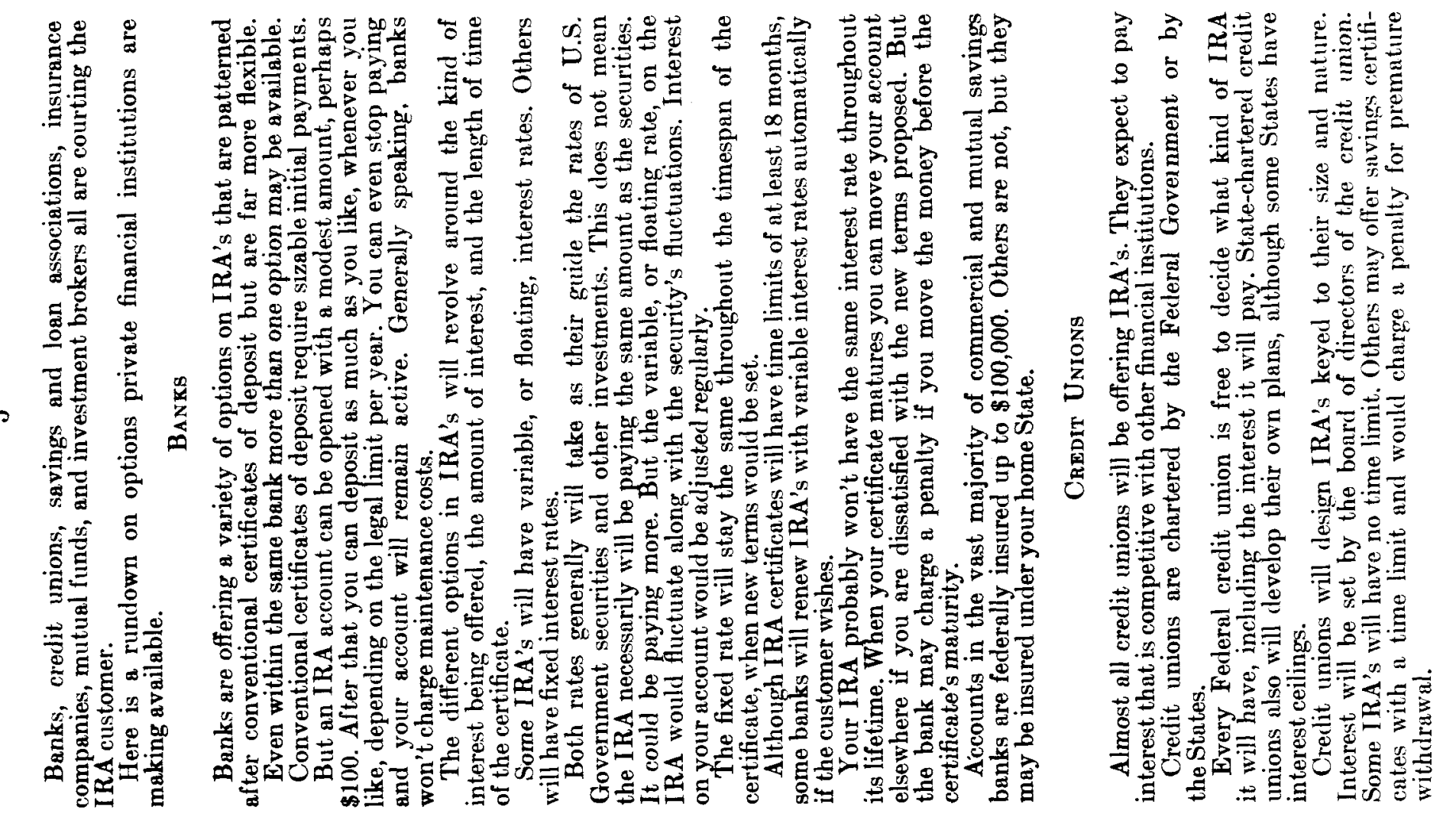

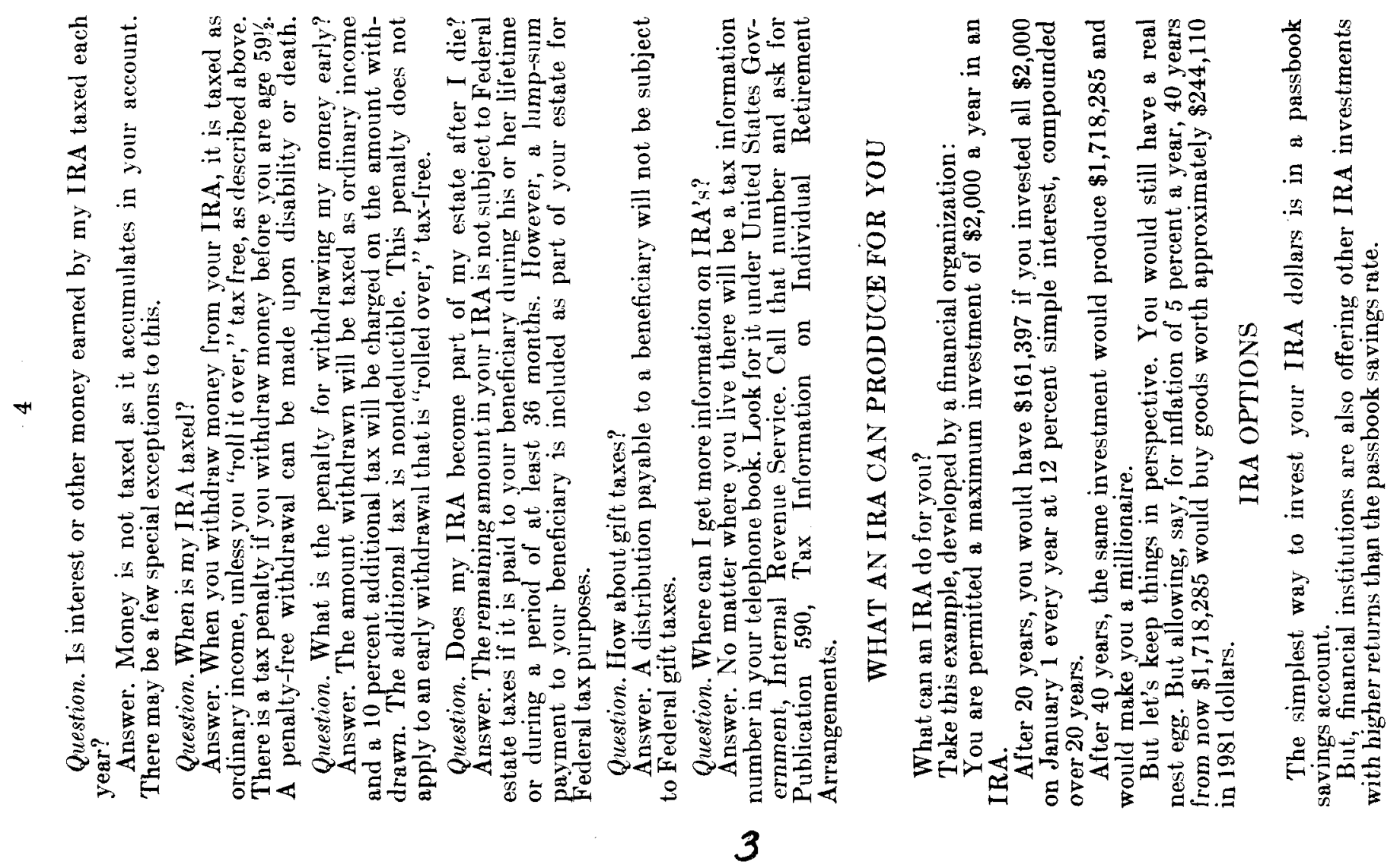




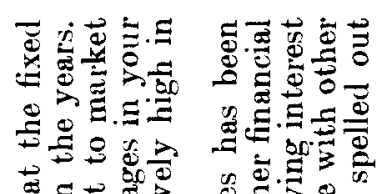

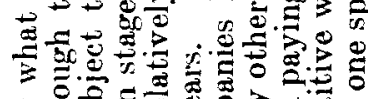
co:

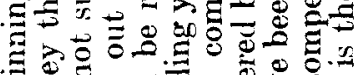

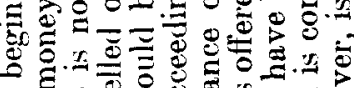

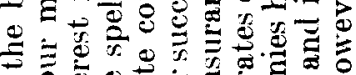

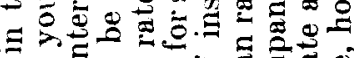

人

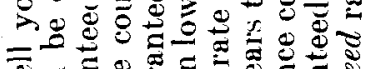

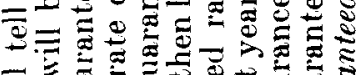

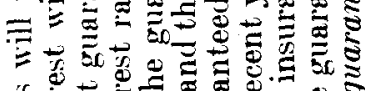

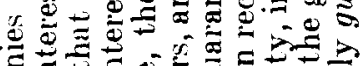
要.

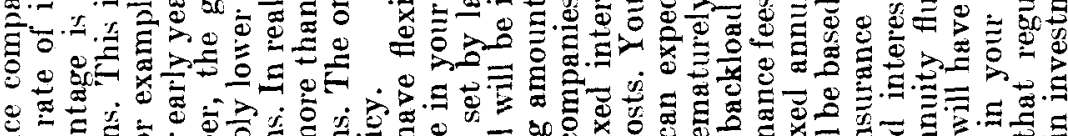

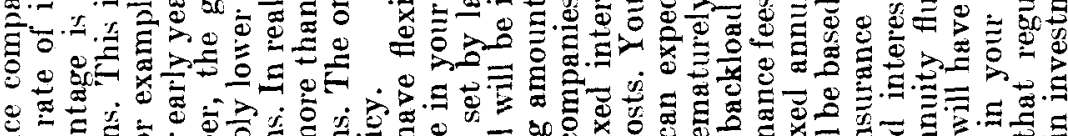

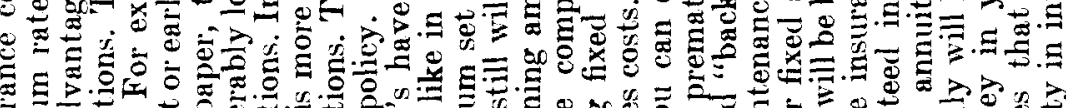

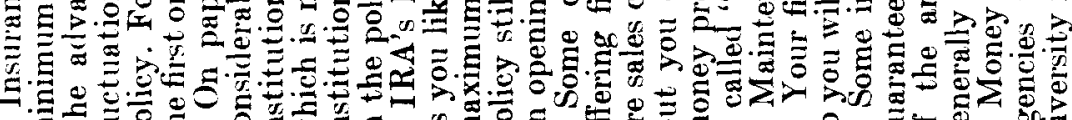

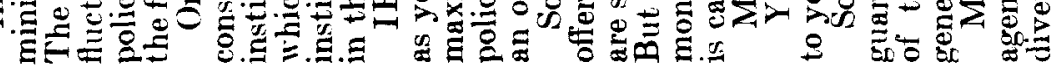

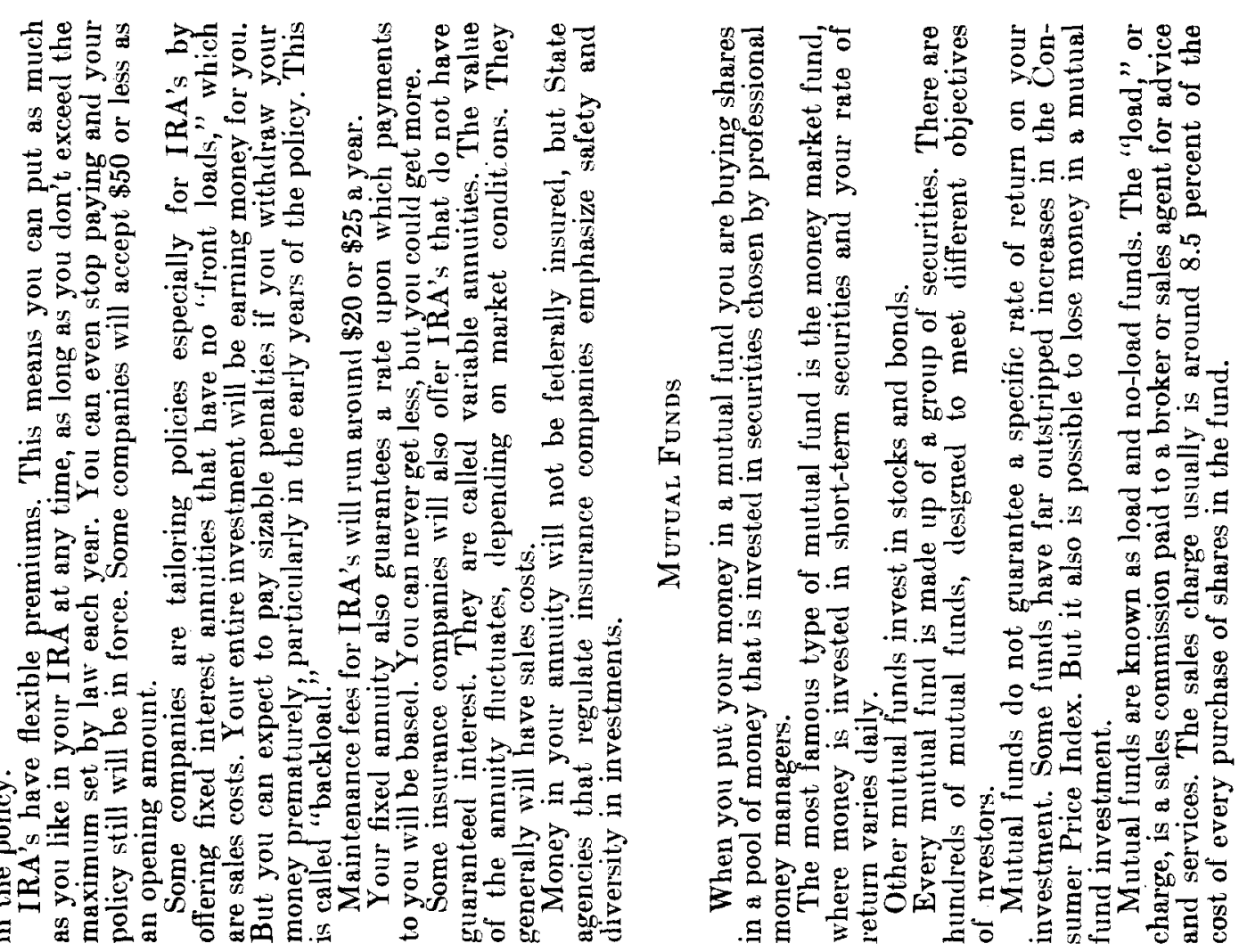

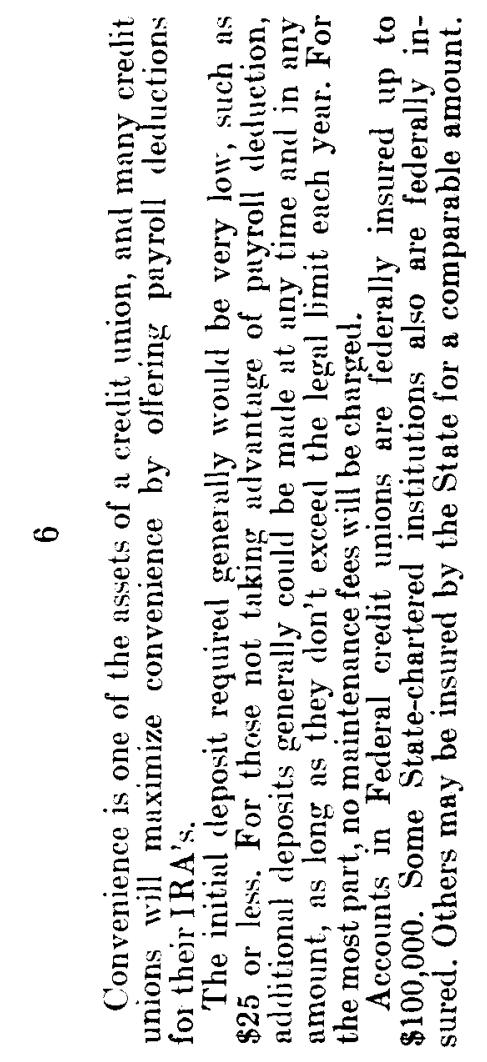

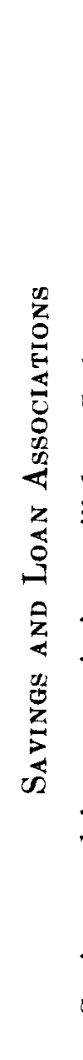

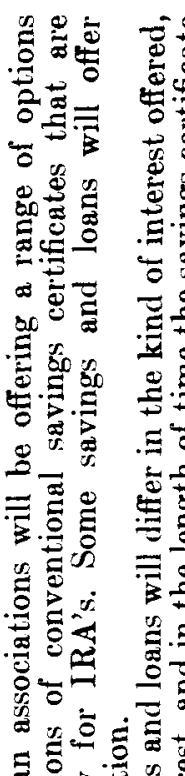

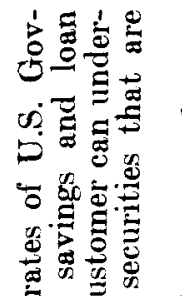

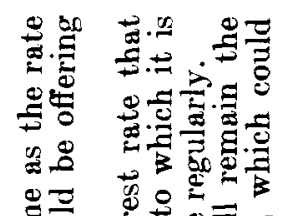

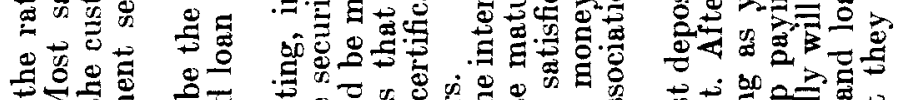

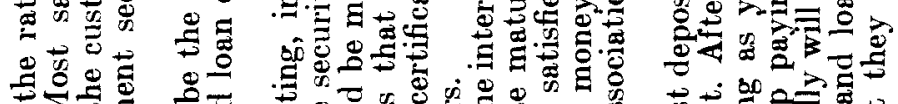

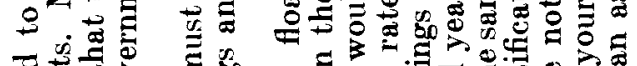

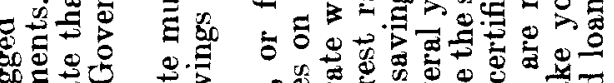

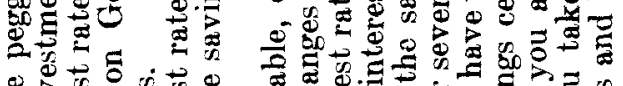

8.0

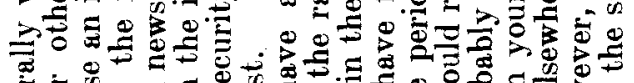

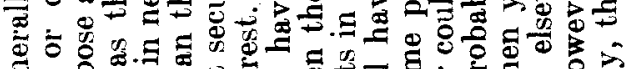

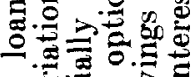

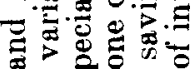

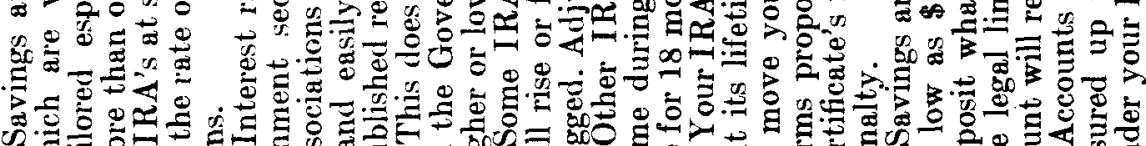

o.

s.

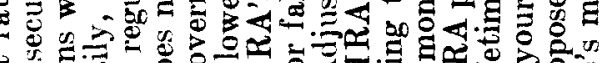

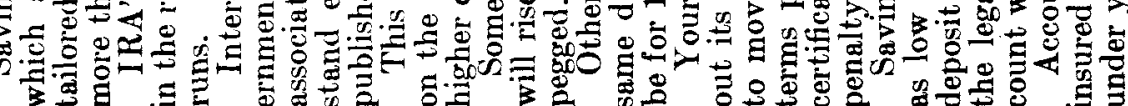

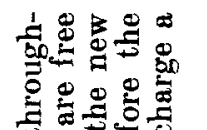

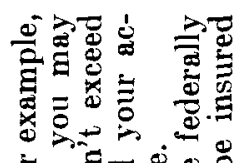

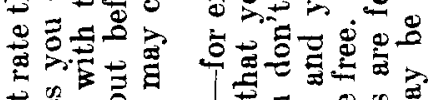

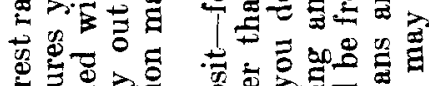

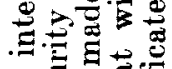

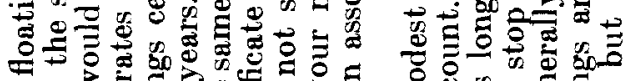

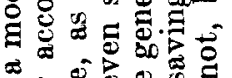

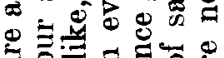

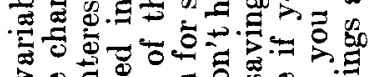

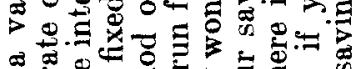

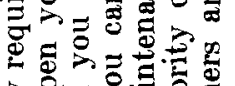

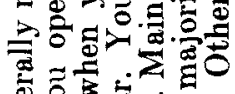

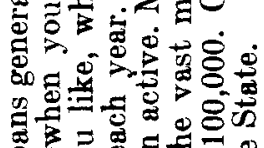

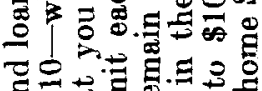

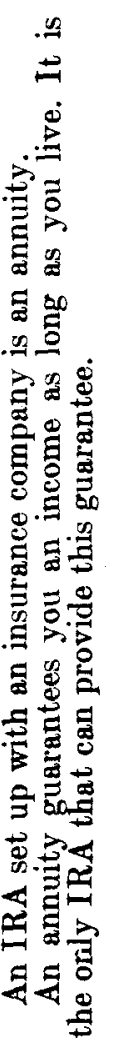

$$
4
$$



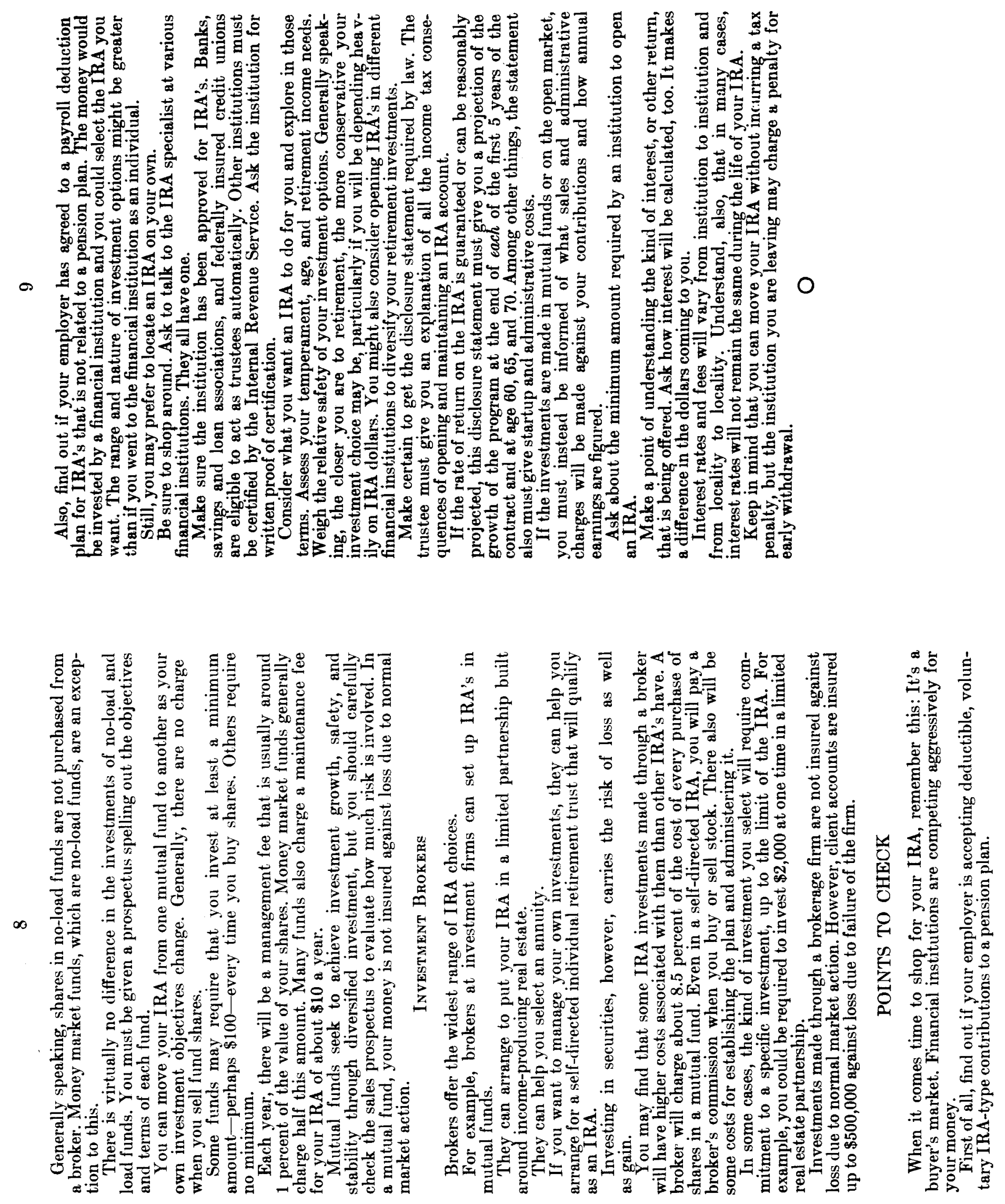


\section{Eest Kays to Gash In On IRA Tax Ereaks}

\section{New savings plans can help you prepare for retirement. But there are rules to follow and choices to make. Here's what you need to know.}

Working Americans who are willing to start socking away cash for retirement are now getting a big new helping hand from Uncle Sam.

Effective January 1, tax breaks reward individuals who put up to $\$ 2,000$ a year into a special savings planknown as an individual retirement account-to build a nest egg for the future. Money put into an IRA can be invested in any number of ways - from simply opening a savings account at a bank to trading in stocks and other securities. You can have a professional manage the money in your account or you can do it yourself.

As a result, a whirlwind of bidding is under way by firms seeking to handle the flood of investment money. Banks, savings and loan associations, mutual funds, credit unions, insurance companies and stockbrokers are all offering IRA investment plans. Some companies are setting up payroll-deduction plans for IRA contributions.

Financial institutions are "fighting tooth and nail" for this money, says William Donoghue, publisher of a newsletter on money-market mutual funds.

The American Bankers Association says more than 50 billion dollars a year could flow into IRA programs, although much of this money will come from cash earmarked anyway for investments and savings.

\section{Tax Benefits}

What makes IRA's attractive are two big tax benefits-

- The money that you contribute to an IRA is deductible from your income before calculating how much federal income tax you owe, even if you don't itemize any other deductions.

For example, a person who would otherwise have annual taxable income of $\$ 28,000$ would only have $\$ 26,000$ after contributing $\$ 2,000$ to an IRA. For a married couple filing a joint return, that reduction means a 1982 tax saving of $\$ 580$. In effect, it costs this couple only $\$ 1,420$ to make a $\$ 2,000$ investment. The savings are bigger for people in higher tax brackets, smaller for people in lower tax brackets.

- Interest and other earnings on the IRA investment, including capital gains, accumulate without being immediately taxed. That lets the value of your IRA snowball since the balance upon which you can earn investment income isn't reduced by a tax bite.

\section{Who's Eligible}

Until this year, IRA's had been limited to people who weren't covered by an employer-sponsored retirement plan. Last year's big tax-reduction bill changed that. Starting in 1982, anyone who gets compensation from employment, including fees for professional services or income from part-time work, can set up an IRA, even if also covered by an employer's retirement plan.

An individual holding a job can put up to $\$ 2,000$ a year into an IRA. Open a separate account for a nonworking spouse who doesn't receive any pay during the year, and you can put away a combined total of $\$ 2,250-$ split in any ratio, but no more than $\$ 2,000$ to either account. If you and your spouse both work, you can each invest up to
$\$ 2,000$. If you run a business, it may pay to hire your spouse part time to allow both of you to have IRA's.

The main limit on IRA contributions is that you can't contribute more than what you receive in on-the-job compensation. That's of special interest to part-time workers. Nor can you make contributions if your only income is from interest, dividends or other nonemployment sources.

As long as you don't exceed the yearly ceiling on contributions, there is no limit to the number of individual IRA's you can have. Moreover, you are not locked into an IRA. Within limits, you can close old IRA's and open new ones, or sometimes switch the type of investment within an IRA. The tax rules don't require you to put money in every year, and the payments you make don't have to be in a lump sum. Some sellers of IRA investments, however, may require a minimum deposit.

Self-employed persons can set up IRA's, too, even if they also have IRAlike Keogh retirement plans.

\section{Retums You Can Get}

The key to benefiting from an IRA is to "start early and contribute consistently," says Gary Strum, a vice president at E. F. Hutton \& Company, the investment firm.

For example, a person who is now 40 years old and pays in $\$ 2,000$ a year to an IRA that earns 8 percent a year compounded quarterly would accumu-

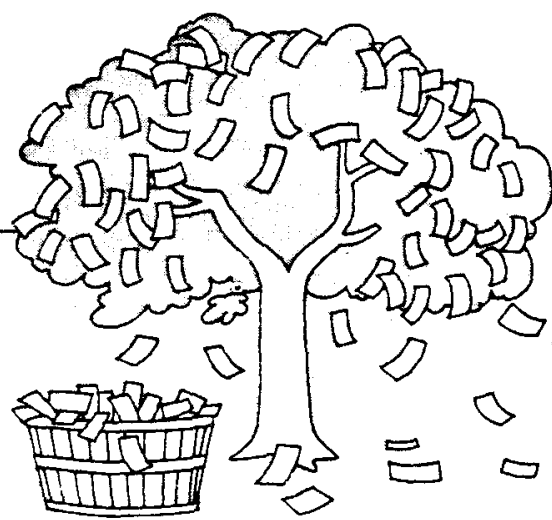

Vs. Inflation's Erosion

When Deposit by Dollars Accumulated at

Started Age $658 \%$ Interest $12 \%$ Interest

$\begin{array}{llll}30 & \$ 70,000 & \$ 393,853 & \$ 1,106,452\end{array}$

$35 \$ \$ 60,000 \quad \$ 256,456 \quad \$ 604,611$

$40 \quad \$ 50,000 \quad \$ 163,999 \quad \$ \quad 326,754$

$45 \quad \$ 40,000 \quad \$ 101,778 \quad \$ \quad 172,911$

$\begin{array}{lllll}50 & \$ 30,000 & \$ 59.905 & \$ & \mathbf{8 7 , 7 3 2}\end{array}$

$\begin{array}{lllll}55 & \$ 20,000 & \$ 31,726 & \$ & 40,570\end{array}$

$60 \quad \$ 10,000 \quad \$ 12,762 \$ 14,458$

Double the amounts for a working couple wo contribute $\$ 4,000$ a year.

Note: Figures assume deposits made at start of period, with interest compounded quarterty.

\begin{tabular}{cccc}
$\begin{array}{c}\text { Annual } \\
\text { Rate of } \\
\text { inflation }\end{array}$ & $\begin{array}{c}\text { Value of Today's } \mathbf{5 1 0 0 , 0 0 0} \text { in } \\
\mathbf{5}\end{array}$ & $\begin{array}{c}\mathbf{1 5} \\
\text { Years }\end{array}$ & $\begin{array}{c}\mathbf{2 5} \\
\text { Years }\end{array}$ \\
\hline $6 \%$ & $\mathbf{\$ 7 4 , 7 2 6}$ & $\$ 41,727$ & $\mathbf{\$ 2 3 , 3 0 0}$ \\
$\mathbf{8 \%}$ & $\mathbf{\$ 6 8 , 0 5 8}$ & $\mathbf{\$ 3 1 , 5 2 4}$ & $\mathbf{\$ 1 4 , 6 0 2}$ \\
$10 \%$ & $\$ 62,092$ & $\$ 23,939$ & $\$ 9,230$ \\
$12 \%$ & $\$ 56,743$ & $\$ 18,270$ & $\$ 5,882$ \\
$14 \%$ & $\$ 51,937$ & $\$ 14,010$ & $\$ 3,779$ \\
\hline
\end{tabular}

Lowion aces 


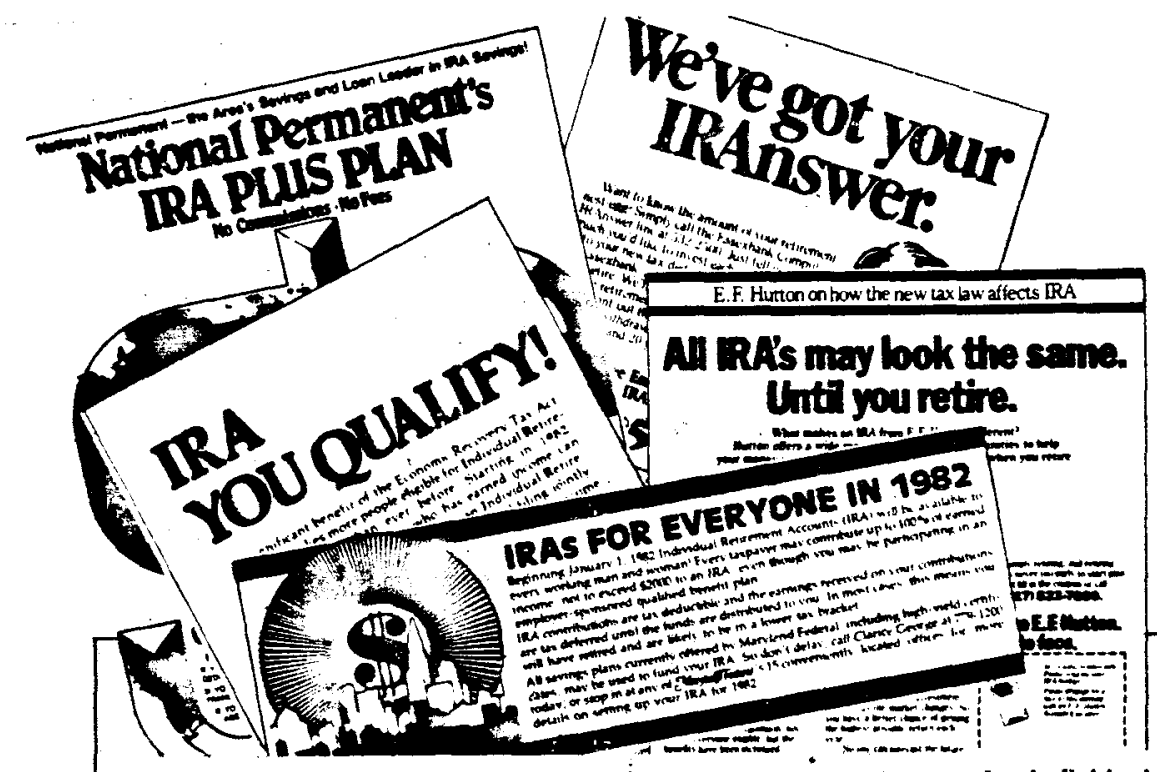

Financlal firms are waging an advertising war to woo cetcomers for individual rotiremont eccounte at take are billions of dollars in now savings.

late $\$ 164,000$ by the time he or she reaches 65 . If the IRA earns 12 percent a year, the balance will reach almost $\$ 327,000$; start at age 30 , and by age 65 you can have more than 1 million dollars stockpiled, even though your contributions totaled only $\$ 70,000$. One New York S\&L advertises: "Retire a millionaire for just $\$ 166.66$ a month."

But don't let the gargantiuan figures blind you. Behind the assumption that you can earn 12 percent a year, for instance, is an assumption that high inflation will continue. If that is so, by the time you retire, 1 million dollars won't be worth nearly as much as it is today.

In addition, an IRA only defers tax; it doesn't exempt you from it. When you start withdrawing funds, you will be taxed on all you take out-at regular income-tax rates. Moreover, no special favor will be given to IRA earnings from long-term capital gains--such as the sale of stock held longer than a year. Capital gains will be taxed the same as other income, rather than at the lower rate that normally applies.

Nevertheless, financial advisers say IRA's still shape up as a good buy. They also riote that the tax bite may be eased at retirement when you presumably will be in a relatively low tax bracket because you won't be working.

In addition, advisers say that people should start IRA's because Social Security and private pensions cannot be counted on to provide all the cash needed for retirement.

Despite the hoopla, there's no need to rush into an IRA. Though opening an IRA early this year will get you a fast start on earning tax-deferred income, you can wait until you file your 1982 tax return in 1983 to open an IRA or make a contribution to one, and still get a 1982 tax deduction. curities, mutual funds, options and real-estate partnerships. Note: Deposits to an IRA must be in cash. You can't contribute assets, such as stocks, you already own.

Also available for investment are special U.S. individual retirement bonds, available from Federal Reserve banks and the Treasury. They yield a relatively modest 9 percent a year.

Specifically prohibited for new IRA investments are gold, art, antiques, diamonds, coins and other so-called collectibles. An alternative is to invest indirectly in such assets-shares in a gold-mining firm, for example.

Experts suggest you stay away from tax-exempt securities, such as municipal bonds. The reason: The interest on such securities are less than on other investments and yet don't escape tax in an IRA-they are taxed when withdrawn.

More controversial is the question of investing in stocks. Some analysts look askance at buying securities for longterm price appreciation because shares held in an IRA don't get favorable long-term capital-gains treatment. Instead, these analysts suggest buying stocks that pay big dividends, or highyielding debt issues such as bonds and government securities, to benefit from the tax deferral in an IRA. Others, however, say that even though you give up capital-gains benefits, stocks may still be the best bet for long-term growth to outpace inflation.

Many employers are allcwing payroll deductions to IRA's; this offers convenience and often lower costs. NCR Corporation in Dayton, Ohio, for one, gives employes a choice. They can funnel their money to NCR's credit union, a mutual fund that is managed by $T$. Rowe Price Associates, or a program run by Connecticut General Life Insurance Company for investing in longterm securities.

The new law also allows employers to accept IRA-style deposits to a firm's own pension plan, although that approach appears to be less popular.

\section{Whthowals}

Though IRA's are billed as a way to save for retirement, your age rather than job status determines when you can withdraw money. You can take cash out without penalty, gradually or all at once, as early as age $591 / 2$, and the balance still accumulates tax deferred.

Unless you become disabled, withdrawals before $591 / 2$ are subject to a tax penalty of 10 percent of the amount withdrawn, in addition to your being hit by income tax. The same age limits on withdrawals apply to a spouse for whom you've opened an IRA. There's no early withdrawal penalty if you die,

U.S.NEWS \& WORLD REPORT, Jan. 11, 1982 
in which case your IRA assets can be passed on to heirs.

Note: You can't get around the earlywithdrawal penalty by borrowing from an IRA or using its assets as collateral for a loan. Do that and you are subject to penalty and tax as if the amount were an early withdrawal.

Nevertheless, advisers say that people shouldn't let the withdrawal penalty scare thern. That's because the tax breaks are so large that in some cases in future years you may come out ahead even if you must incur the penalty.

You must start withdrawing from an IRA after you reach 701/2. At that point, the withdrawals must be at a rate fast enough to deplete the IRA over either your life expectancy or the joint expectancy of you and your spouse. You can make contributions to an IRA up to the year in which you reach $70 \% / 2$.

But even people under $591 / 2$ can take out IRA funds temporarily without incurring a penalty or tax. Once a year you can close an IRA and hold the funds for up to 60 days before rolling them over into a new account to avoid tax or the 10 percent penalty. You can use the funds as a short-term loan or invest them to get current income.

If you want to switch an IRA more than once a year, the institution holding your account must transfer it to the hew institution, thus keeping the funds out of your hands and preventing you from being hit with tax or peralty. Note: Though you avoid tax penalties in such a transfer, you may run into extra charges levied by the institution in which you have your IRA-an early. withdrawal penalty on a savings certificate or a redemption fee on an insurance annuity, for example.

\section{The Cost}

When opening an IRA, there are often initial charges to pay, as well as an annual fee, sometimes based on the value of the account. But the levies are generally small. Banks and S\&L's usually charge nothing to open an IRA and $\$ 10$ or less a year to maintain it. Many mutual funds charge $\$ 5$ to $\$ 10$ to open an IRA and less than $\$ 10$ a year to keep it up. Self-directed accounts at stockbrokers may cost up to about $\$ 30$ to open, with a maintenance fee of about $\$ 25$ or higher depending on the account's size and typé. You also pay commissions on the purchase of stocks and some mutual-fund shares and insurance annuities.

The best advice: Shop around, don't be misled by fancy sales pitches and be wary of promises of high future yields that may not be met.

BY LEONARD WIENER 


\section{By JiLL BetTw}

saff Reporter of THE: W ALL STrket Jourkal

For millions of people, the question isn't whether to open an individual retirement account (IRA) after Jan. 1, but where.

Financial institutions, brokerage firms, eredit unions, insurance companies and mutual funds are all competing for your business, as you have undoubtedly noticed from the barrage of advertising in recent weeks.

Whatever investment you choose, any amount that you contribute to your IRA will be tax-deductible, up to $\$ 2,000$ a year, or a total of 2,250 for yourself and a nonworking spouse. The earnings can be left to accumtlate iax-free until you reach at least age sots.

Deciding how to Invest depends on the

risk you will accept in return for a possibly higher tax-free yield, whether you want to control your IRA yourself or have it professionally managed. and how much you want to pay in assorted fees (see accompanying tablel.

No matter where you put your IRA dollars, if you dip into the account before age 5o4, you will pay a penalty tax of $10 \%$ on the amount withdrawn. And, the money you take out will be taxed as ordinary income.

For instance, if you accumulate $\$ 10,000$ in an IRA and decide to take out $\$ 2,000$ before you reach the magic age, you will pay a penalty tax of $\$ 200$. The other $\$ 8,000$ will remain sheltered. If, however, the $\$ 10,000$ was invested in a bank certificate of deposit or an insurance annuity, you-could also pay other penalties for getting at the money early.

Still, the tax penalties for early withdrawals from an IRA aren't prohibitive. Af ter a few years, they can effectively be paid out of tax-free interest.

(Note: While annual contributions to the new universal IRA are a write-off on your federal tax return starting in 1982 , many states, including New Jersey and California. haven't amended their laws to make the contributions deductible from state income taxes. Most state legislatures, however, are expected to act in time for claiming the full deductions for 1982.$)^{\circ}$
Any fees for setting up or maintaining an IRA are also deductible from federal taxes, whether you choose to pay them out of your annual contributions or separately. Here is a sample of the types of investments available from various institutions:

Banks, Thrift Institutions and Credit Unions. The options inciude certificates of deposit with a choice of maturities, as well as regular passbook savings accounts. Their fees are the lowest, and IRAs are federally insured, up to $\$ 100,000$.

New are 18-month certificates, permitted only for IRAs and Keoghs, which are retire ment plans for the self-employed. These "wild-card" CDs can carry any interest rate that a financial institution chooses to pay. Most banks and savings and loans are currently advertising rates of between $14 \%$ and $15 \%$ on either fixed- or variable-rate 18 month certificates. Minimum deposits can be as low as $\$ 1$. Credit unions can vary the term. as well as the rate, on any certificate they decide to offer.

If you have an existing IRA or Keogh, and you are stuck with an old, low-interest savings certificate that hasn't matured, you can avoid an early-withdrawal penalty and still start earning more on contributions toward your retirement savings from now on.

A financial institution can assess an early-withdrawal penalty, which requires you to forfejt at least the last six months' interest. only if you invade the certificate's principal. But you can withdraw the accumulated interest without penalty any time. (The same is true of any kind of savings certificate.)

Use the interest you have piled up to open a higher-paying IRA or Keogh, and direct that the future interest on your old cer tificate also be paid to the new plan. It is called "bleeding" an account, and although banks hate people who do it, few of them charge any lee for such automatic interest transfers.
Brokerage Firms. The big brokerage houses offer the most variety of invest ments, although you will pay more in fees for your IRA than you will at financial insti. tutions. And brokerage retirement accounts aren't covered by federal deposit insurance.

Basically, there are two ways to go. 'A self-directed IRA lets you buy and sell stocks and bonds as you like, or control investments in such things as real estate, oil and gas or equipment leasing. At Paine Webber Jackson \& Curtis Inc., investors can buy mortgage securities insured by the Government National Mortgage Association (Ginnie Mae). The fees, which are typical of those the firm changes for all of its self-directed accounts, are $\$ 25$ to open an IRA, brokerage commissions of $\$ 30$ per $\$ 1,000$ invested, plus a $\$ 25$ annual maintenance, or custodial, fee.

Merrill Lynch will charge $\$ 30$ to open any kind of self-directed IRA, plus brokerage commissions. The annual maintenance fee will be the greater of 350 , or two-tenths of $1 \%$ of the assets in the account as of Dec. 31 each year. Bache Halsey Stuart Shields Inc. - will have fees of $\$ 25$ and a minimum annual tee of $\mathbf{3 3 5}$.

The lower-cost route at a brokerage firm is to invest in any of the professionally managed mutual-fund packages the firm sells. Typlcally, the packages include a moneymarket fund and several types of stock funds and bond funds. Also available are funds that combine stocks and options. There is usually a fee of about $\$ 5$ to switch out of one fund and into another.

Merrill Lynch will charge $\$ 15$ to set up a mutual-fund account, pius an annual custo dial fee of $\$ 20$. Dean Witter Reynolds Inc. will charge $\$ 20$ and $\$ 20$, respectively.

"No-Lasd" Mutual Fund "Familles." Firms like the Fidelity Group, the Dreyfus Service Corporation, T. Rowe Price and the Vanguard Group offer IRA investors several professionally managed funds without sales charges. 
At most companies there won't be a charge for setting up the account or for switching between funds. Annual management fees typically will run $\$ 10$ or less.

All of the big companies are also aggressively marketing their-funds for payroll-deduction IRAs. If your employer offers such a plan, participating in it could cost you less than buying the funds directly.

Insurance Companies. The products are called Individual Retirement Annuities. Their biggest selling point is that they are guaranteed to provide a certain amount of income each year after you retire. The pay. out, per $\$ 1,000$ you invest, is based on average life expectancies, as weil as the value of the investments purchased with premiums.

There are two main types of insurance IRAs. Prudential, for instance, will offer a "front-loaded" annuity that will carry a sales charge of $8.75 \%$, which cornès off the top of each $\$ 1,000$ you put in over the years. The initial interest rate, which will be adjusted annually, will be $13.75 \%$. The annual maintenance charge will be $\$ 8$ on the first payment, \$1 on any subsequent payments There won't be any penalties to withdraw part of your funds.

Prudential will also have a "back. loaded" annuity that will pay $13 \%$ to start. There aren't any sales charges on this type of contract, but there is a penalty of $7 \%$ if you withdraw any money in the first year. That penalty scales down gradually until it disappears entirely in the eleventh year. The annual maintenance fee is $\$ 25$, starting in the second year.

Several insurance companies will also offer variable-rate amuities that invest in mutual funds. Northwestern Mutual Life's plan will give buyers the choice of a money-market fund, stock fund or NML 1, a fund that will move in and out of various investments "as market conditions warrant," a company spokesman says. This is another backloaded plan, which will charge a penalty of $8 \%$ of principal for withdrawals made in the first five years. The annual maintenance fee is $\$ 30$.

\begin{tabular}{|c|c|c|c|c|}
\hline & \multirow{2}{*}{$\begin{array}{l}\text { Investment } \\
\text { Choices }\end{array}$} & \multicolumn{3}{|c|}{ How Much You Will Pay } \\
\hline & & $\begin{array}{c}\text { Initial Charges to } \\
\text { Open Accoint }\end{array}$ & $\begin{array}{l}\text { Annual } \\
\text { Maintenance or } \\
\text { Management } \\
\text { Fees }\end{array}$ & $\begin{array}{c}\text { Early Withdrawa } \\
\text { Penates }\end{array}$ \\
\hline \multirow{2}{*}{$\begin{array}{l}\text { Banke and } \\
\text { Thritt institutions }\end{array}$} & $\begin{array}{l}\text { Certiticates } \\
\text { of deposit }\end{array}$ & \multirow[t]{2}{*}{ Usually none. } & \multirow{2}{*}{$\$ 10$ or less } & $\begin{array}{l}\text { Minimum } \\
\text { six months } \\
\text { interest }\end{array}$ \\
\hline & Savings accounts & & & None \\
\hline \multirow{2}{*}{$\begin{array}{c}\text { Self-Directed } \\
\text { Brokernge Firms } \\
\text { "Load Funds }\end{array}$} & $\begin{array}{l}\text { Stocks bonds, } \\
\text { Ginnie Maes. } \\
\text { real estate, } \\
\text { oil and gas } \\
\end{array}$ & None to $\$ 30$ & $\begin{array}{l}\$ 25 \cdot \$ 50, \\
\text { plus any } \\
\text { brokerage } \\
\text { commissions }\end{array}$ & None \\
\hline & $\begin{array}{l}\text { Money-market, } \\
\text { stocks bonds. } \\
\text { stocks and options }\end{array}$ & $\left\{\begin{array}{l}81,2 \% \text { of } \\
\text { investment }\end{array}\right.$ & $\begin{array}{l}\$ 2-\$ 9 \\
\$ 5 \text { to } \\
\text { switch funds }\end{array}$ & None \\
\hline \multirow[t]{2}{*}{ Credit Unions } & $\begin{array}{l}\text { Centificates } \\
\text { of deposit }\end{array}$ & \multirow[t]{2}{*}{ None } & \multirow[t]{2}{*}{ Usuaily none. } & $\begin{array}{l}\text { Minimum } \\
\text { six months } \\
\text { interest }\end{array}$ \\
\hline & Savings accounts & & & None \\
\hline \multirow{2}{*}{$\begin{array}{l}\text { Inşurance Cos. } \\
\text { LBack-Loso" }\end{array}$} & $\begin{array}{l}\text { Fixed-premium } \\
\text { annuities }\end{array}$ & $\begin{array}{l}8 \%, \% \text { of } \\
\text { investment }\end{array}$ & $\begin{array}{l}\text { About } \\
\$ 8-\$ 10\end{array}$ & $\begin{array}{l}\text { Usually } \\
\text { none }\end{array}$ \\
\hline & $\begin{array}{l}\text { Variable-premium } \\
\text { annuities }\end{array}$ & None & $\begin{array}{l}\text { About } \\
\$ 25-\$ 30\end{array}$ & $\begin{array}{l}7 \%-8 \% \\
\text { first year }\end{array}$ \\
\hline $\begin{array}{l}\text { "No-Lond" } \\
\text { "Mutual Fund } \\
\text { "Familles" }\end{array}$ & $\begin{array}{l}\text { Money -market, } \\
\text { stocks, bonds. } \\
\text { stocks and options }\end{array}$ & 55 or less & $\begin{array}{l}\text { S10 or less } \\
\text { free } \\
\text { switching }\end{array}$ & None \\
\hline
\end{tabular}




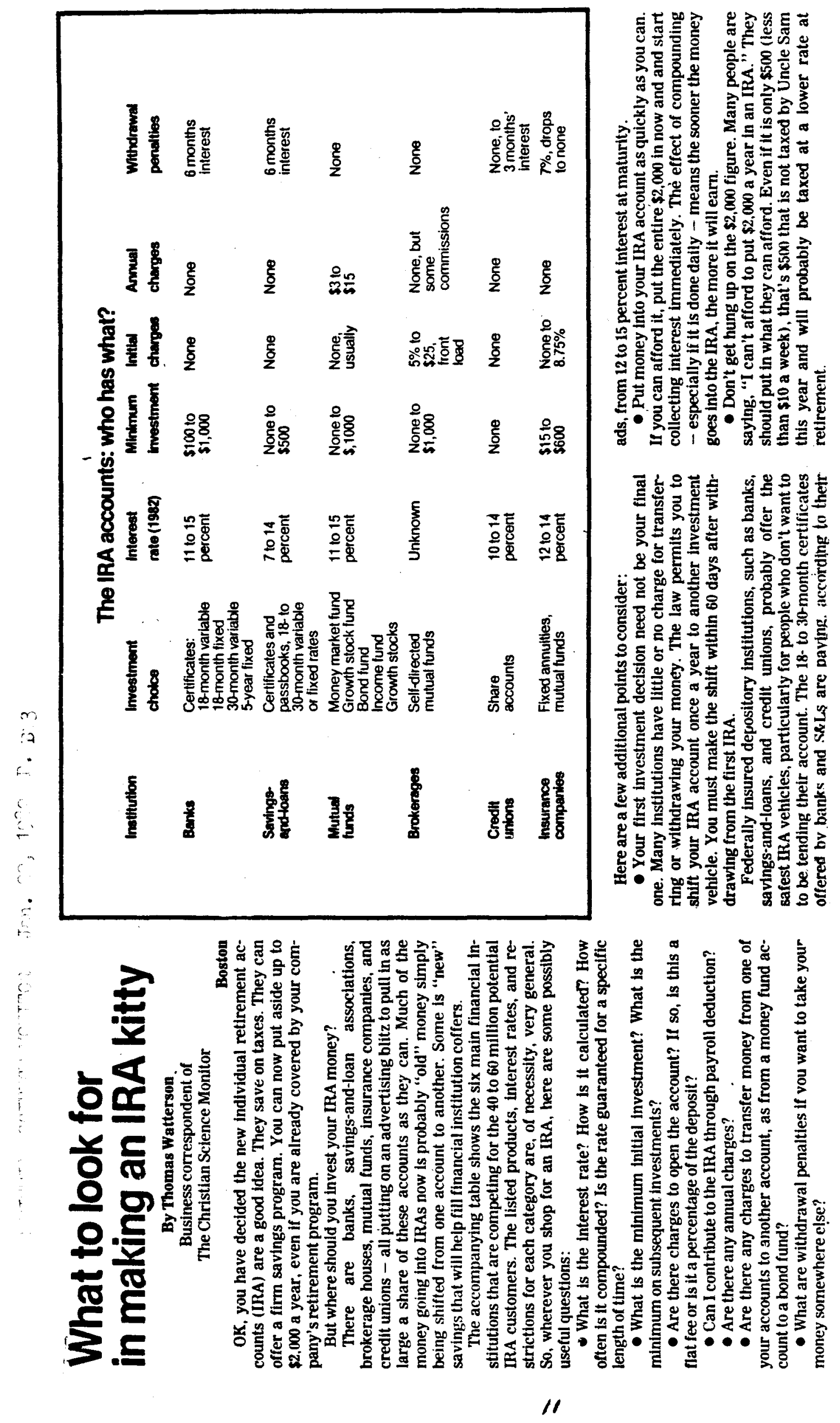




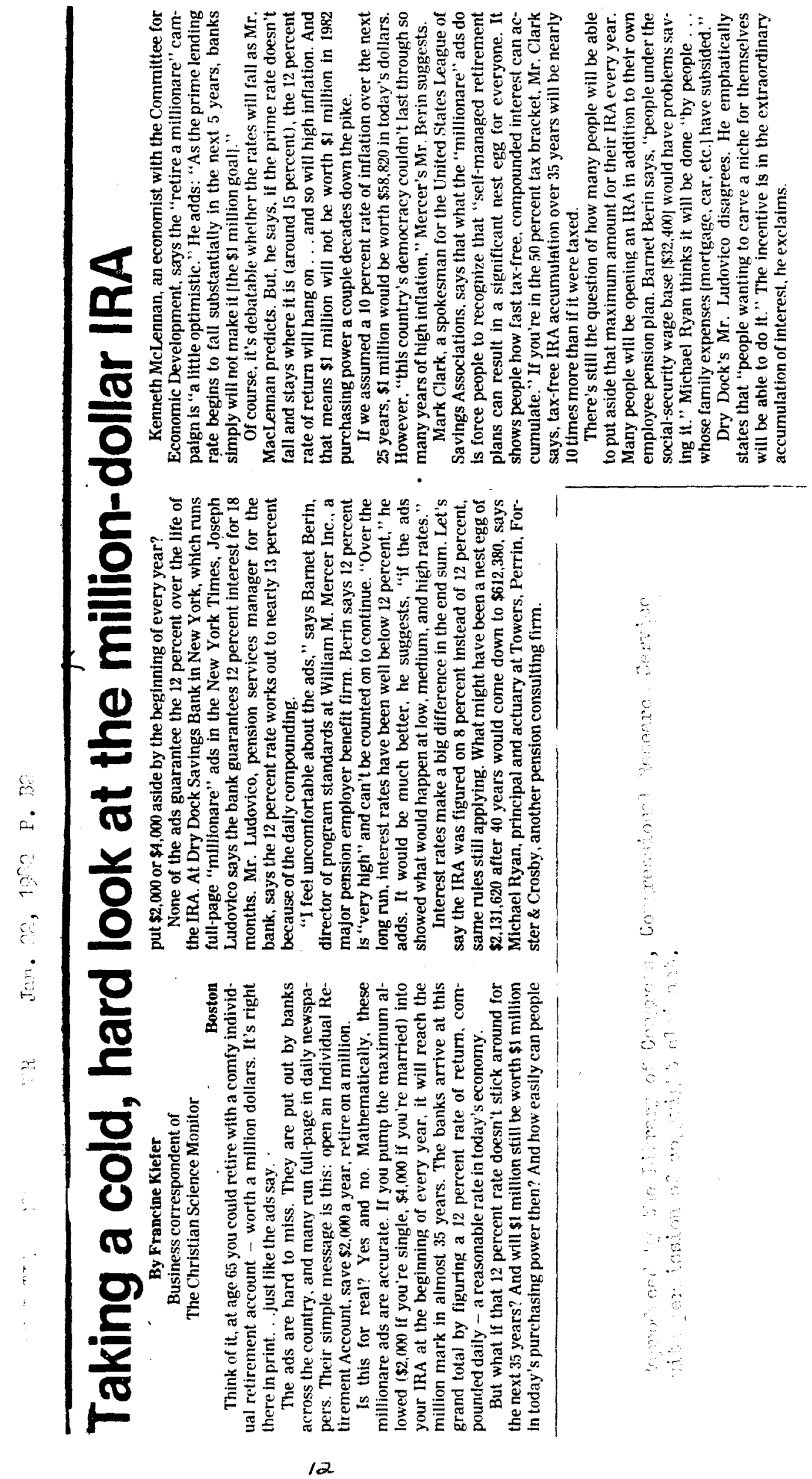

